International Journal of Business Management and Economic Review

Vol. 4, No. 06; 2021

ISSN: 2581-4664

\title{
THE EFFECT OF IMPLEMENTATION OF GOVERNMENT ACCOUNTING STANDARD, GOVERNMENT INTERNAL CONTROL SYSTEM AND ACCOUNTING INFORMATION SYSTEM ON GOOD GOVERNANCE REQUIREMENT WITH THE QUALITY OF FINANCIAL STATEMENT AS MODERATION OF GOVERNMENT WORKING UNIT (SKPA) IN THE GOVERNMENT OF ACEH, INDONESIA
}

\author{
Reza Alfarisi, Nadirsyah and Muslim A. Djalil* \\ Faculty of Economics and Business, Universitas Syiah Kuala Banda Aceh, Indonesia
}

http://doi.org/10.35409/IJBMER.2021.3341

\begin{abstract}
The purpose of the study is to examine the impact of the implementation of Government Accounting Standard, Government Internal Control System, Accounting Information System and Quality of Financial Statement on the implementation of good governance in the SKPA of Aceh Government. The population in this study are all the SKPA of Aceh Government, amounting to 46 SKPA consisting of offices, agencies, offices and secretariat. The respondents in this study were the head of SKPA as the Budget User Authority, the Financial Administration Officer (PPK), the Treasurer of Expenditures and the PPK Assistant at the Office, Agency, Office and Secretariat. Because this research uses moderating variables, the data analysis technique uses interaction regression. The results of the hypothesis test show that the implementation of good governance in the SKPA of the Aceh Government is influenced in part by government accounting standard, government internal control system, accounting information system and the quality of financial statement. Interaction test results show that the quality of financial statement strengthens the effect on the relationship between government accounting standard and government internal control system. However, the quality of the financial statement weakens the impact of the relationship between the accounting information system and the implementation of good governance.
\end{abstract}

Keyword: Innovation, Total Factor Productivity (TFP), Small and Medium Enterprises (SMEs) in Vietnam

\section{INTRODUCTION}

The government as the party called the public sector is the party that manages public finances requires good governance. Because it involves spending public money, it becomes important for citizens, users and taxpayers to know how this money is spent and how the quality of services is provided. Good governance leads to good management, good performance, good public money investment, good public behavior and good results (Juiz, Guerrero and Lera, 2014).

The implementation of regional autonomy is the implementation of a system of good governance characterized by increased regional independence, transparency and public accountability, more socially responsive regional governments, increased public participation in regional development, increased efficiency and effectiveness of financial management and public services, and increased democratization in the region (Mahmudi, 2010). 


\section{International Journal of Business Management and Economic Review}

Vol. 4, No. 06; 2021

ISSN: 2581-4664

The application of good governance in the field of financial management, one of which is through the imposition of obligations to all regional heads to prepare Regional Government Financial Report (LKPD). As a result of the audit, not all regional governments prepare financial reports in accordance with the Government Accounting Standards (SAP) and other applicable regulations. Some findings indicate weaknesses in the preparation of financial statements, so that after being examined only 27 percent received LKPD PAPs from 415 entities, BPK Chairperson Hadi Purnomo (2011) claimed 326 local governments, or 91 percent from 358 regions.

The number of audit findings by the BPK audit shows that the quality of inspectorate officials is still relatively low. (www.bpk.go.id). According to Azwar Abubakar (2010), the State Minister for Administrative Reform and Bureaucratic Reform, the Government requested the holding of a Financial and Development Supervisory Agency (BPK) to achieve good financial governance in each government. Because the financial management system in the area is bad.

The Government Accounting Standards, in accordance with Government Regulation No. 71 of 2010 are a concrete effort to achieve transparency and accountability in the financial management of central and regional governments. Efforts were made to submit accountability reports in the form of financial statements. The resulting government financial reports must meet the principles on time (Suhaeti \& Suhendar, 2015).

Weaknesses in good governance in the public service sector are characterized by inefficient organizational bureaucracy, poor quality of services to the public, difficulties in eradicating corruption, collusion and nepotism, and a lack of community participation in development.

The phenomenon that is taking place in the development of the public sector in Indonesia today is the strengthening of accountability demands for public institutions, both at the central and regional levels. According to Mahmudi (2010) and Mardiasmo (2009) accountability can be interpreted as an obligation of an agent (government) to manage resources, report and disclose all activities and activities related to the use of public resources to the mandate giver or trustee who has the right and authority to hold them accountable.

To achieve accountability demands on public institutions, a Government Internal Control System (SPIP) is required. The Government issued Government Regulation No. 60 of 2008 concerning the Government Internal Control System (SPIP). The control system is expected to achieve its objectives, namely reliable financial reporting.

Good governance also requires the implementation of reliable accounting information systems. In the context of regional ownership, the regional government accounting information system refers to PP-65 of 2010 concerning regional financial information systems. The system is based on a computer network that connects and handles data consolidation between SKPD (Regional Apparatus Work Unit) and SKPKD (Regional Financial Management Work Unit) so that data in local government can be well integrated. Based on Permendagri 64 of 2013, the Accounting Information System is an accrual-based accounting system that provides comprehensive information to stakeholders (Mas'ut \& Masrura, 2018).

The greatest contribution of government accounting information systems to the quality of financial statements is the use of software and documentation procedures. Good software has good control and shows good data processing so that the possibility of data processing errors is very minimal.

\section{LITERATURE REVIEW}


International Journal of Business Management and Economic Review

Vol. 4, No. 06; 2021

ISSN: 2581-4664

Effect of the Implementation of Government Accounting Standard on the Realization of Good Governance

The regional financial accounting system is more of a set of procedures that govern all processes and activities that exist in the recording of regional finances, so that the regional financial accounting system can regulate all activities in the recording, recording, reporting and accountability process, so that the regional financial accounting system can regulate how a regional financial system becomes more structured, directed, quality and can be easily understood and accounted for.

According to (Djalil, Ramadhanti, Jalaluddin, Yahya and Nadirsyah, 2017) Internal control has a strong influence on efforts to prevent fraud and irregularities that exist in an organization. In government, the practice of irregularities such as corruption, collusion and nepotism, as well as lawlessness, is still the case, not apart from the weakness of the internal control system. Internal control systems must be designed as well as possible so that the resulting performance is effective and efficient.

\section{Effect of the Implementation of Government Internal Control System on the Realization of Good Governance}

Appropriate internal control functions are more widely used and synergistically implemented to achieve good governance in the public sector to encourage transparency and accountability in the management of state finances. In other words, the internal audit function will improve good governance (Kewo \& Afiah, 2017).

\section{Effect of the Implementation of Accounting Information System on the Realization of Good Governance}

The accounting information system is a formal system designed to provide information. The application of information systems is very important because it can reflect the transparency and accountability of a procedure or method used and can be applied to achieve good corporate governance (Jastika, 2018).

\section{Effect of the Quality of Financial Statement on the Realization of Good Governance}

Good performance accountability will have an impact on the performance of government officials in providing services to the public. The quality of audible and audited financial statements can increase the credibility of local government performance accountability (Ningtyas et al., 2019).

Abdul and Abdullah's research (2006) states that regional financial reports can be said to be of high quality if the financial reports presented annually receive an assessment in the form of Opinion from the Financial Supervisory Agency (BPK). When BPK gives an Unqualified Opinion (WTP) to the LKPD report, it means that it can be said that the financial statements of local government entities are presented and disclosed in a reasonable and quality manner.

Effect of the Quality of Financial Statements on the Relationship between Government Accounting Standard and the Realization of Good Governance

According to Mardiasmo (2002), a tool to facilitate the creation of public accountability is through the presentation of comprehensive Regional Government Financial Statement. In line with 
the implementation of regional autonomy and fiscal decentralization, the challenges faced by public sector accounting are to provide information that can be used to monitor local government accountability. This includes financial accountability, managerial accountability, legal accountability, political accountability, and policy accountability.

\section{Effect of the Quality of Financial Statements on the Relationship between Government Internal Control System and the Realization of Good Governance}

According to (Aprilia, Marietza, Baihaqi and Ririzkita, 2015) accountability is an important key to good governance. This has been regulated in Government Regulation No. 60 Government internal control system, 2008. Good governance will be achieved when the government reveals its performance in the form of financial statements. With the availability of quality financial reports, it is almost certain that the internal control system applied is good and can encourage an nd assist the relevant agencies in implementing good governance.

Effect of the Quality of Financial Statements on the Relationship between Accounting Information System and the Realization of Good Governance

The financial statements are the primary tool of government responsibility to the people's representatives in parliament or institutions of interests of other countries and the general public. In Indonesia, the accountability report is presented in the State Budget/Regional Budget (APBD) budget records.

Accounting information systems play an important role in achieving good corporate governance in organizations because accounting information systems produce key financial statements that will be used by stakeholders (Christopher, Guay, Joseph, Link and Armstrong, 2010).

The quality of government financial reports can be generated through the implementation of an accrual-based accounting system. Through the quality of financial reports, it's expected that the implementation of accounting information systems will be fully implemented to achieve good governance in the local government environment.

\section{Research Hypothesis}

Based on the framework that has been explained before, this research hypothesis can be formulated as follows:

The implementation of government accounting standards, government internal control systems, accounting information systems and the quality of financial statements all have an impact on the achievement of good governance.

The implementation of government accounting standards has influenced the achievement of good governance.

The Government's internal control system influences the achievement of good governance.

Accounting information systems affect the achievement of good governance.

The quality of financial statements affects the achievement of good governance.

The quality of financial statements influences the relationship between government accounting standards and the achievement of good governance.

The quality of the financial statements affects the relationship between the Government's internal control system and the achievement of good governance.

The quality of financial statements affects the relationship between accounting information 
International Journal of Business Management and Economic Review

Vol. 4, No. 06; 2021

ISSN: 2581-4664

systems and the achievement of good governance.

\section{RESEARCH METHOD}

The population in this study was all Dinas/Agency, Office and Secretariat in the Government of Aceh, amounting to 46 SKPA (www.acehprov.go.id). Sample selection in this study using the census method. The sample taken from this study is based on a questionnaire returned by respondents. Respondents in this study are employees who have positions as Budget User Authorities, Financial Administration Officers (PPK), Expenditure Treasurer and Assistant Financial Administration Officials (PPK Assistants) in each SKPA who become the research sample.

A total of 92 respondents to this study returned a questionnaire consisting of two officials/staff from each SKPA. There are 10 SKPA that did not return the questionnaire. The number of questionnaires that did not return was 20 questionnaires. The questionnaire didn't return 100 percent because not some respondents weren't present at the time of taking the questionnaire, and there were damaged questionnaires and missing questionnaires. The questionnaires were returned intact and up to 92 questionnaires could be processed. The research data were analyzed using moderated regression analysis, namely the interaction regression model or Moderate Regression Analysis (MRA).

Operationalization of Variable

Dependent Variable:

Realization of Good Governance

Good governance is a form of acceptance of the importance of a set of rules or good governance to regulate the relationships, functions and interests of various parties in business affairs and public services (Azlina \& Amelia, 2014). Indicators for assessing good governance are transparency, fairness, accountability and responsibility (Syamsir, 2014).

\section{Independent Variable}

\section{Government Accounting Standard}

SAP is the guideline and basis for government, both central and regional governments in preparing and presenting government financial reports.Sanjaya et al., 2017). According to PP No. 71 of 2010, the SAP assessment indicators are commitment, human resources, infrastructure and information systems

\section{Government Internal Control System}

SPIP is an integral process of actions and activities carried out continuously by the leadership and all employees to provide adequate confidence in the achievement of organizational goals (Sanjaya et al., 2017). SPIP assessment indicators according to PP No. 60/2008. Control environment, risk assessment, control activities, information and communication and internal control monitoring.

Accounting Information System

AIS is a system that processes data and transactions to produce useful information for planning, controlling, and operating a business (Halimatusadiah \& Gunwan, 2014). According to Krismiaji (2010). SIA assessment indicators are usefulness, economy, reliable power, availability, 
International Journal of Business Management and Economic Review

Vol. 4, No. 06; 2021

ISSN: 2581-4664

timeliness, customer service, capacity, practicality, flexibility, traceability, audit power and security.

\section{Moderating Variable \\ Quality of Financial Statements}

The quality of financial statements is a qualitative feature of financial statements and is a normative measure that needs to be implemented in accounting information to enable it to meet its objectives. (PP No. 71 of 2010). Indicators for evaluating the quality of financial statements are useful to users of financial statements, which can correct and predict the timeliness of financial reporting, completeness of information and honest presentation.

Design of Hypotheses Test

The hypothesis testing criteria are as follows:

H01: $\beta 1=\beta 2=\beta 3=\beta 4=0$; The independent variable has no effect on the dependent variable.

There is at least one $\beta i \neq 0, i=1,2,3,4$; The independent variable influences the dependent variable.

\section{RESULTS AND DISCUSSIONS Result of Validity Test}

The validity of the data in this study was evaluated statistically, using the Pearson productmoment coefficient of correlation test with the help of SPSS. On the basis of the output results, after evaluating the validity of all statements submitted on the questionnaire (35 statement items) and meeting the requirements for further testing, where the correlation coefficient value is above 0,1735 (based on the table of critical correlation values $r$ product-moment for $n=91$ ), the productmoment $r$ value for $n=91$ is 0,1735 .

\section{Result of Reliability Test}

The reliability test was seen based on the results of the Cronbach Alpha calculation where the reliability measurement of the variables in this study showed that the reliability measurement met the requirements of $\alpha>0,6$.

Result of Hypothesis Testing

The results of the interaction regression or Moderate Regression Analysis (MRA) can be seen in Table 1.

Table 1 Result of Research Variable Interaction Regression

\begin{tabular}{|c|l|l|}
\hline $\begin{array}{l}\text { Dependent } \\
\text { Variable }\end{array}$ & $\begin{array}{l}\text { Independent } \\
\text { Variable }\end{array}$ & $\begin{array}{l}\text { Unstandardized } \\
\text { Coeficients } \\
\text { B }\end{array}$ \\
\hline $\begin{array}{c}\text { Good } \\
\text { Governance }\end{array}$ & Constanta & $-4,381$ \\
\cline { 2 - 3 } & SAP & $-0,735$ \\
\cline { 2 - 3 } & SPIP & $-0,059$ \\
\cline { 2 - 3 } & SIA & 1,025 \\
\cline { 2 - 3 } & KLK & 0,482 \\
\hline
\end{tabular}


International Journal of Business Management and Economic Review

Vol. 4, No. 06; 2021

ISSN: 2581-4664

\begin{tabular}{|l|l|l|}
\hline \hline & Moderat1 & 0,022 \\
\hline & Moderat2 & \\
\hline & Moderat3 & \\
\hline & Coefisien Correlation $(\mathrm{R})=0,794$ \\
\hline & R Square $R^{2}=0,630$ \\
\hline & Adjusted R Square $=0,599$ \\
\hline & Std. Error of the Estimate $=1,490$ \\
\hline
\end{tabular}

$\mathrm{GG}=-4,381-0,735 \mathrm{SAP}-0,059 \mathrm{SPIP}+1,025 \mathrm{SIA}+0,482 \mathrm{KLK}+0,022 \mathrm{SAP} * \mathrm{KLK}+$ $0,009 \mathrm{SPIP} * \mathrm{KLK}-0,032 \mathrm{SIA} * \mathrm{KLK}+\varepsilon$

Based on the regression equation above, it can be seen that the constant $(\alpha)$ of $-4,381$ indicates that if the Government Accounting Standards, Government Internal Control Systems, Accounting Information Systems and Quality of Financial Statements are considered constant, the magnitude of the Realization of Good Governance will decrease by 4,381 units

\section{The Effect of the Implementation of Government Accounting Standard on the Realization of Good Governance}

The results of the hypothesis test show that the regression coefficient value of -0.735 and $t-$ statistic value of -1.386 are smaller than the t-table value of 1.98761 (t-statistics $<t$-table) and the p-value of 0.131 is greater than 0.05 alpha $(>0.05)$. These results indicate that government accounting standards have a negative and not significant effect on the achievement of good governance.

By applying Government Accounting Standards (SAP), there will be an accountable and transparent government in the field of financial management in accordance with the principles of Good Governance.

\section{Effect of the Implementation of Government Internal Control System on the Realization of Good Governance}

The results of testing the hypothesis that with an alpha degree of 5\% (0.05) the regression coefficient value of -0.059 and the t-statistic value of -0.105 are smaller than the t-table value of 1.98761 (t-statistics <t-table) and the value of $\mathrm{p}$ value of 0.894 is greater than alpha of 0.05 (> $0.05)$. These results indicate that the internal control system of government has a negative and not significant effect on the realization of good governance. According to Partolo (2007), internal control and good governance have a close relationship, where the better the internal control is applied, the better the implementation of good governance.

\section{Effect of the Implementation of Accounting Information System on the Realization of Good Governance}

The test results show that the regression coefficient value of 1.025 with an alpha degree of 5 percent $(0.05)$ is greater than the $t$-table value of 1.98761 ( $t$-statistics $>t$-table) and the p-value of 0.005 is smaller than alpha $0.05(<0.05)$. These results indicate that the accounting information system has a positive and significant impact on the achievement of good governance.

With the implementation of the Accounting Information System (SIA), it is expected that accountability in the management of regional tax revenues can be achieved so that the government 
International Journal of Business Management and Economic Review

Vol. 4, No. 06; 2021

ISSN: 2581-4664

can be held accountable to the public and ultimately can allocate available funds to improve services to community and regional development.

\section{Effect of the Quality of Financial Statements on the Realization of Good Governance}

The results of the hypothesis test show that the alpha degree of 5 percent $(0.05)$ yields a regression coefficient of 0.482 and the t-statistic value of 2.911 is greater than the t-table value of $1.98761(\mathrm{t}$ statistic $>t$-table) and the p-value of 0.005 is smaller than alpha $0.05(<0.05)$. These results indicate that the quality of financial statements has a positive and significant impact on the achievement of good governance.

Local governments can make financial reports as a tool to control and evaluate the performance of government and local government work units (internal), while external users use local government financial reports as a tool for accountability and decision-making.

Effect of the Quality of Financial Statements on the Relationship between Government Accounting Standards and the Realization of Good Governance

Following the inclusion of the quality variable in the financial statements as a moderating variable, the relationship between government accounting standards and the implementation of good governance has been positive. Thus, it can be said that the quality of financial statements strengthens the effect on the relationship between government accounting standards and the achievement of good governance.

Effect of the Quality of Financial Statements on the Relationship between Government Internal Control System and the Realization of Good Governance

The relationship between the Government's internal control system and the implementation of good governance has changed positively following the inclusion of the financial report quality variable as a moderating variable. Thus, it can be argued that the quality of financial statements strengthens the effect on the relationship between the government's internal control system and the achievement of good governance.

Effect of the Quality of Financial Statements on the Relationship between Government Internal Control System and the Realization of Good Governance

After the inclusion of the financial statements quality variable as a moderating variable, the relationship between the accounting information system and the implementation of good governance changed to negative. Thus, it can be argued that the quality of the financial statements weakens the relationship between the accounting information system and the implementation of good governance.

\section{CONCLUSION \& RECOMENDATION}

\section{Conclusions}

Government accounting standard affect SKPA's implementation of good governance in the Aceh government.

The government's internal control system influences the implementation of good governance in SKPA 


\section{International Journal of Business Management and Economic Review}

Vol. 4, No. 06; 2021

ISSN: 2581-4664

The accounting information system influences the implementation of good governance in SKPA

The quality of the financial statements affects the implementation of good governance in SKPA in the Aceh Government.

The quality of the financial statements affects the relationship between government accounting standards and the achievement of good governance at SKPA in the Aceh Government.

The quality of the financial statements affects the relationship between the Government's internal control system and the achievement of good governance at SKPA in the Aceh Government.

The quality of the financial statements affects the relationship between the accounting information system and the implementation of good governance in SKPA in the Aceh Government.

\section{Recommendations}

Operational

To improve the quality of local government financial reports, the Government of Aceh recommends that:

Continue to improve SPIP within the Aceh Government. SPIP monitoring must be evaluated so that the institution has a renewable and well-connected system.

To facilitate education and training for financial managers, in particular to implement any changes in regulations concerning regional financial management so that financial reports can be presented in accordance with regulations and on time.

The Aceh Government needs to place competent institutions in accordance with their educational background and expertise and direct all employees to the maximum extent possible in carrying out their duties and responsibilities, especially in the public service and administration, so that transparency, accountability and responsibility to the community can be further enhanced.

Academic

For further researchers, other variables that are thought to influence the implementation of good governance in government agencies, such as understanding the regional financial accounting system, organizational commitment, and organizational culture, should be added.

For further researchers, direct and in-depth interviews with research respondents are better conducted so that the information obtained from the research results can be represented and explained to the actual situation.

\section{REFERENCES}

Aprilia, N., Marietza, F., Baihaqi, \& Ririzkita, T. (2015). Participatory Budgeting, Government Internal Control Systems and Implementation of Government Accounting Standards to Achievement of Good Goverment Governance Principles. In The 16Th malaysia-Indonesia International Conference on Economics, Management, and Accounting (MICEMA) 2015 (pp. 116-135).

Azlina, N., \& Amelia, I. (2014). Pengaruh Good Governance dan Pengendalian Intern Terhadap Kinerja Pemerintah Kabupaten Pelalawan. Jurnal Akuntansi Universitas Jember, 12(2), 32-42.

Christopher, S., Guay, W. R., Joseph, P., Link, C., \& Armstrong, C. S. (2010). The Role of Information and Financial Reporting in Corporate Governance and Debt Contracting. Journal 


\section{International Journal of Business Management and Economic Review}

Vol. 4, No. 06; 2021

ISSN: 2581-4664

of Accounting \& Economics, 50(2), 179-234.

Djalil, M. A., Ramadhanti, S. V., Jalaluddin, Yahya, M. R., \& Nadirsyah. (2017). The Effect of Used Information Technology, Internal Control, and Regional Accounting System on the Performance of City Governance Agency of Banda Aceh City, Indonesia. BRAND. Broad Research in Accounting, Negotiation, and Distribution, 8(1), 25-37. Retrieved from https://www.edusoft.ro/brain/index.php/brand/article/view/684/761.

Halimatusadiah, E., \& Gunwan, B. (2014). Analisis Penerapan Good Corporate Governance Dalam Mengoplimalkan Pelaksanaan Sistem Informasi Akuntansi. Jurnal Riset Akuntansi Dan Keuangan, 2(1), 300-313. https://doi.org/10.17509/jrak.v2i1.6583

Kewo, C. L., \& Afiah, N. N. (2017). Does Quality of Financial Statement Affected by Internal Control System and Internal Audit? International Journal of Economics and Financial Issues, 7(2), 568-573.

Krismiaji. (2010). Sistem Informasi Akuntansi. Yogyakarta: UPP STIM YKPN.

Mahmudi. 2010. Manajemen Kinerja Sektor Publik, UPP STIM YKPN, Yogyakarta. Mardiasmo. 2009. Akuntansi Sektor Publik. Andi Offset. Yogyakarta.

Mas'ut, \& Masrura, A. (2018). Pengaruh penerapan sistem informasi akuntansi terhadap akuntabilitas pendapatan pajak daerah di badan pengelola pajak dan retribusi kota medan. Jurnal Riset Akuntansi Multiparadigma, 5(1), 29-37.

Ningtyas, H. I. R., Roekhudin, \& Andayani, W. (2019). The Effect of Government Internal Control System and Government Accounting System on Performance Accountability With The Financial Quality Statements As Intervening Variables (Case Study: The Government of Lumajang Regency, East Java). International Journal of Business, Economics and Law, 18(5), 179-187.

Sanjaya, A., Rasuli, M., \& Haryani, E. (2017). Pengaruh Penerapan Standar Akuntansi Pemerintahan, Sistem Pengendalian Intern, Sistem Akuntansi Keuangan Daerah, dan Sumber Daya Manusia Terhadap Kualitas Laporan Keuangan Pemerintah Daerah dengan Komitmen Organisasi Sebagai Pemoderasi (Studi Pada SKPD Ka. JOM Fekon, 4(1), 366-

380.

Suhaeti, N., \& Suhendar, D. (2015). Pengaruh Implementasi Standar Akuntansi Pemerintahan (SAP) dan Sistem Pengendalian Intern Pemerintah (SPIP) terhadap Kualitas Laporan Keuangan pada Pemerintahan Daerah Kabupaten Kuningan. JRKA, 1(2), 90-105.

Syamsir, T. (2014). Pengaruh Peran Inspektorat Daerah dan Budaya Organisasi Daerah Terhadap Penerapan good Governance (Studi Empiris Pada Pemerintah Kota Bukit Tinggi). Jurnal Akuntansi, 2(2).

Retrieved from http://ejournal.unp.ac.id/students/index.php/akt/article/view/1046/740 